\title{
CROSS-LINGUISTIC INFLUENCE OF THE CUZCO QUECHUA EPISTEMIC SYSTEM ON ANDEAN SPANISH
}

\author{
MARILYN S. MANLEY \\ Rowan University
}

1. INTRODUCTION. Since the time of the Spanish Conquest, the Quechua and Spanish languages have been engaged in intense contact. Particularly in the city of Cuzco, Peru, once the geographical and cultural center of the Incan Empire and a common destination today for many Quechua-speaking peasant migrants, it is possible to observe the necessary communication of Quechua and Spanish speakers on a daily basis. As is generally the case in research about language contact, studies concerning QuechuaSpanish cross-linguistic influence have most often focused on the mutual influence of the Quechua and Spanish lexicons as well as on the level of phonology. This paper seeks to add to the literature concerning cross-linguistic influence on the levels of morphosyntax, semantics, pragmatics and discourse. The level of discourse, particularly, has often been ignored in language contact studies. More specifically, this work seeks to clarify and inform the current debates regarding the semantics and pragmatics of the Quechua epistemic markers and the ways in which these markers exert cross-linguistic influence on Andean Spanish, through the use of data gathered among Quechua-Spanish bilingual speakers of Cuzco Quechua.

\section{LITERATURE REVIEW.}

2.1. DISAGREEMENT: THE SEMANTICS OF QUECHUA EPISTEMICS. Works on Quechua linguistics published approximately within the last fifty years, including scholarly articles as well as texts meant to be used by those learning Quechua as a second or foreign language, have included both more-detailed and less-detailed accounts of the semantics and pragmatics of the Quechua epistemic markers. While scholars generally agree that the Quechua epistemic marker -chá indicates conjecture, disagreement and inconsistency has centered on the semantics and pragmatics of the remaining four epistemic markers -mi/-n, -si/-s, -rqa-, and -sqa-. The three epistemic suffixes, -mi/-n, si/-s, and -chá, may be attached to words of any grammatical category while the two past tense verb forms, -rqa- and -sqa-, occur only with verbs. An understanding of the claims in the literature concerning the semantics and pragmatics of the Quechua epistemic system is essential to the discussion of the ways in which these markers exert influence on Andean Spanish. Here, the author presents a sampling of findings that encompass the broad range of claims made to date regarding the semantics and pragmatics of the Quechua epistemic system.

According to Cusihuamán (1976:240-241), $-m i /-n$ is used by speakers to refer to events in which they have personally participated or have seen directly, as fully conscious, aware individuals, and -si/-s is used by speakers to describe events they have learned about through indirect means, such as from other people or other sources of information, such as books, newspapers, radio, or television. Furthermore, Cusihuamán (1976:168-170) states that the past tense, -rqa-, is used to refer to completed actions that were carried out with the conscious control and direct participation of the speaker, while the past tense, -sqa-, is used to describe events that were carried out by the speaker in an 
unconscious state or without the direct participation of the speaker. Therefore, according to Cusihuamán, both $-m i /-n$ and -rqa- are used to describe information obtained through direct means, and both $-s i /-s$ and -sqa- may be used to describe information obtained through indirect means. De Granda (2001) corroborates Cusihuamán’s claims for -mi/- $n$, -si/-s, -rqa-, and -sqa-, and Lee (1997:41) supports Cusihuamán’s claims regarding -rqaand - sqa-.

The findings of Dedenback-Salazar Sáenz (1997:152), however, cast doubt on the claims of Cusihuamán and de Granda. In her examination of the epistemic forms used in the Huarochirí texts, "the oldest known source on Andean culture written in an Andean language”, she observes, “... in the chapters that relate a coherent narrative, usually of mythical character, we find the combination of the reportative evidential suffix - si and the -rka- past tense..." As Cusihuamán and de Granda claim that the use of -si/-s indicates that information has been obtained through indirect means and that the use of rqa- indicates that information has been obtained through direct means, they would be unable to account for the combination of the two epistemic markers.

Weber (1986) raises the question of whether the Huanuco Quechua epistemic suffixes -mi, -shi, and -chi, which are the Huanuco Quechua equivalents of the Cuzco Quechua $\mathrm{mi} /-n$, -si/-s, and -chá, should be thought of as primarily expressing distinctions regarding information source (e.g. first-hand vs. second-hand), or distinctions regarding attitudes toward the information (e.g. truth-value, level of certainty, involvement, responsibility). Wölck’s (1987:53) findings corroborate Weber's (1986) claims, as he finds - $m i /-n$ and si/-s to be distinguished primarily based on the category of truth-value, with $-m i /-n$ indicating a higher level of truth-value than - si/-s. Regarding the past tenses, Wölck (1987:59-60) finds -rqa- to be used in the description of more recent past events, while sqa- is found to be used to refer to more distant past events that were not witnessed by the speaker. Nuckolls (1993) also claims that the primary and general meaning of $-m i /-n$ across all dialects of Quechua is to signal a high level of certainty regarding the truth of the message. Nuckolls (1993) goes on to state that a secondary or applied meaning of $\mathrm{mi} /-n$ is to signal that the information was witnessed first-hand by the speaker.

2.2. REINTERPRETATION OF THE SPANISH PRESENT PERFECT AND PAST PERFECT VERB TENSES. In Klee and Ocampo's study (1995:54), which focused on the use of Spanish verb forms, “...in narrative clauses which require the preterite or historical present in standard Spanish...”, the authors find Calca (Peruvian) QuechuaSpanish bilinguals to reinterpret the meanings of the present perfect and past perfect verb tenses in Spanish so as to express an epistemic distinction. For these Quechua-Spanish bilinguals, the present perfect verb tense in Spanish was claimed to be used to convey information that had been obtained through being a direct witness, while the past perfect verb tense in Spanish was claimed to be used to "...indicate that the speaker has not witnessed the action or state described by the verb or that the speaker was unaware of the situation" (1995:62). The authors sum up this finding by stating that, "The temporal distance that these tenses mark in standard Spanish is transposed to an evidential distance in bilingual Spanish” (1995:64). In his description of the Quechua-influenced Spanish of Bolivia and Peru, Lipski mentions the same phenomenon (1996:214,348).

Escobar (1997:864) corroborates Klee and Ocampo's (1995) claims, when she finds that native Quechua speakers of Cuzco use the present perfect verb tense with an 
evidential function in Spanish in order to "...refer to past events which took place at a location other than the one the speaker is in at the moment of the speech event for the purpose of emphasizing them as events experienced or witnessed by the speaker...”. Escobar attributes this 'evidential use' of the present perfect to the influence of the -mi/-n Quechua epistemic clitic. In contrast, Escobar claims, "In Spanish in contact with Quechua, the pluperfect indicates that the information given is not first-hand, i.e. the pluperfect is used to mark reported information" (1997:865). Escobar attributes the use of the past perfect tense to the influence of the -si/-s Quechua epistemic clitic.

In contrast to Escobar's attribution of the claimed epistemic uses of the Andean Spanish present perfect and past perfect to the influence of the Quechua epistemic clitics, -mi/-n and -si/-s respectively, Lee (1997:41) attributes this example of morphosyntactic cross-linguistic influence from Quechua to Spanish to the influence of the Quechua past tense verbal forms, -rqa- and -sqa-. Lee (1997:102-3) indicates that there is disagreement in the literature as to whether the use of -rqa- in Quechua correlates with the use of the present perfect, past perfect, or preterite Spanish verb tenses. This same disagreement exists with reference to the correlation of the use of -sqa- in Quechua with the various Spanish verb tenses. De Granda agrees with Lee in attributing the restructuring of the Spanish perfect tenses to the influence of the Quechua past tense verbal forms, -rqa- and -sqa-, and refers to the restructured forms as 'function calques' (2001:152-3).

It is important to note that findings similar to those described here for Quechuainfluenced Andean Spanish have also been noted in the case of the Aymara-influenced speech of Bolivia. Quechua-Aymara language contact predates the contact of either indigenous language with Spanish. Similarities between Quechua and Aymara, such as the fact that both languages make use of an epistemic system, have led many scholars to investigate the possible genetic relationship of the two languages. In his study of La Paz Spanish, Laprade (1981:223) proposes that an Aymara substratum influence is responsible for an epistemic usage of the pluperfect in Spanish, which "expresses the aspect of surprise and nonpersonal knowledge upon encountering an unknown or something seen for the first time or something that occurred without one realizing it...”. Stratford (1991:168-9) corroborates Laprade’s claim for La Paz Spanish. Also, Martin (1981:205 for La Paz Spanish) finds the preterite to be used to indicate direct knowledge and the pluperfect to be used to indicate indirect knowledge, resulting from Aymara influence.

2.3. 'DICE' EPISTEMIC CALQUE. Besides the Quechua epistemic system's influencing the restructuring of the Spanish perfect verb tenses in order to convey epistemic meaning, according to Klee and Ocampo (1995:63), Lipski (1996:214,348), and de Granda (2001:127), the Spanish dice; dicen; diciendo 's/he says; they say; saying', may be used as calques of the Quechua suffix -si/-s in order to express the fact that information has been obtained indirectly. It is interesting to note that Laprade (1981:2212) has also found forms of decir to be used in La Paz Spanish, in sentence-final position, in order to mark the preceding information as "nonpersonal knowledge". De Granda also observes that in regions of Ecuador, Peru, and Argentina, where the use of the -si/-s suffix among Quechua speakers is gradually disappearing, speakers may instead use conjugations of the Quechua verb niy 'to say', in place of the -si/-s suffix (i.e. nin, 's/he 
says' and ninku, 'they say'). De Granda suggests that, in this case, the Quechua speakers are using conjugations of niy as calques of the Spanish calques, dice/dicen (2001:127). Furthermore, according to de Granda, the only Quechua clitic that has been transferred to Andean Spanish as a function calque is -si/-s. Therefore, claims de Granda, the other epistemic clitics in Quechua, -mi/-n and -chá, do not exert cross-linguistic influence on Andean Spanish as function calques (2001:153-4).

2.4. 'PUES' EPISTEMIC CALQUE. The findings of Virginia Zavala (2001) contradict de Granda's (2001) claim that -si/-s is the only Quechua epistemic clitic calqued in Andean Spanish. According to Zavala (2001), Ayacucho (Peruvian) bilingual Quechua-Spanish speakers may use the Spanish conjunction, pues 'well; then; since; therefore; because', as a function calque for the Quechua clitic, -mi/-n. Furthermore, she maintains, due to cross-linguistic influence of the Quechua agglutinative structure, the discourse marker, pues, "...has been transformed and restructured into an item which functions almost as a 'suffix', attached to various parts of speech" (2001:1004). Therefore, according to Zavala, these speakers are using pues in Spanish where they would be using the -mi/-n suffix in Quechua. Through her analysis of the particle, pues, in terms of its use within discourse, Zavala finds common qualitative and quantitative patterns among the use of the particle by her ten informants. She summarizes the use of pues as follows (2001:1017), "The speaker attaches pues to his utterance and with it, the sentence acquires a connotation of conviction, certainty, and assurance towards what he is saying”. A prominent pattern in her data is that the discourse marker/function calque, pues, appears in all cases in clause-final position. Zavala finds the clause-final position for pues to be influenced by Quechua's agglutinative structure in which suffixes are attached onto the ends of words to form different meanings. In the case of the Aymarainfluenced La Paz Spanish, Laprade (1981:215-16) also finds pues, or its reduced form, ps with "a strongly sibilant character", to occur "almost exclusively in post position", "postposed to nearly all parts of speech", in order to "reflect the speaker's attitude or mood".

2.5. 'SIEMPRE' CALQUE. Beyond the appearance of forms of decir and pues as function calques in La Paz Spanish, due to Aymara influence, Laprade (1981) also finds that the Spanish siempre 'always', nomás 'only', and pero 'but', have undergone restructuring. According to Laprade (1981:219-220), in La Paz Spanish, nomás, pues, and pero are found alone or in various combinations at the end of utterances, similar to the way in which suffixes are combined in Aymara. As the present work will propose that siempre is used in Andean Spanish as a function calque for the Quechua -mi/-n, it is useful to note Laprade's claim regarding the use of siempre in La Paz Spanish. Laprade (1981:218) attributes the restructured use of siempre to influence from the Aymara suffix, -puni, and states that in La Paz Spanish, siempre "functions as an emphatic expression" and is used in interrogative constructions to request affirmation. Although Laprade (1981:218) finds the Aymara-influenced siempre to occur "after the elements whose meaning it modifies", he notes that in other regions, "siempre may occur initially, medially, or finally”. Laprade (1981:218) goes on to state that the Aymara suffix, -puni, is regularly translated into Spanish as siempre and "...indicates surprise that the speaker 
has not changed intent, that some aspect of the situation deserves special mention or emphasis, as well as other emphatic meanings”.

Quechua also makes use of a suffix, -puni that is also often translated into Spanish as siempre. According to Aráoz and Salas (1993:128), among the meanings communicated by the Quechua suffix, -puni, are that an action will be carried out without fail and a high level of certainty. As will be described in more detail below, the present work proposes that siempre is used in Andean Spanish as a function calque for the Quechua $-m i /-n$. The author asserts that the restructuring of siempre in Andean Spanish is due to the influence of $-m i /-n$ rather than -puni, as the frequency of use of the restructured siempre is much higher than that of -puni in Quechua. The frequency and distribution of the restructured siempre is more similar to that of $-m i /-n$ in Quechua. It is true, however, that the semantics of the Quechua - mi/-n and - puni overlap, in that they both may communicate a high level of certainty. Perhaps the restructuring of siempre in La Paz, noted by Laprade, is due to the influence of the Quechua - mi/-n or the equivalent Aymara epistemic marker, rather than -puni.

It is also possible that the restructured usage of siempre has extended its influence outside of Andean Spanish in Peru and La Paz Spanish in Bolivia, as the RAE lists decididamente 'decidedly' and definitivamente 'definitively' as possible meanings of siempre in Colombia. According to Lee (1997:24), although the number of Quechua speakers living in Colombia today is much lower than the number that existed during the reign of the Incan Empire, a population of Quechua speakers still exists in the southwestern section of Colombia, close to the border with Ecuador.

3. DATA AND METHODOLOGY. The data and analyses presented here, within a qualitative approach, are based on fieldwork carried out in Cuzco, Peru among bilingual Quechua-Spanish speaking members of two non-profit governmental agencies, the Asociación Civil, 'Gregorio Condori Mamani' Proyecto Casa del Cargador, 'Gregorio Condori Mamani Civil Association, House of the Carrier Project' (CdC), and El Centro de Apoyo Integral a la Trabajadora del Hogar, 'Center for the Integral Support of the Female Home Worker' (CAITH). The CdC is a temporary home for primarily adolescent males, the majority of whom earn a living as cargadores, 'carriers', by transporting agricultural goods within the large market places of Cuzco. The objective of the CdC is to improve the quality of life of the peasant migrant carriers, thereby allowing them to attain respectable levels of health, education, and family well-being. The main goal of CAITH is to offer educational support and assistance to female adolescent domestic servants, who come from rural areas outside of the city of Cuzco. CAITH also functions as a temporary home for these female domestic servants. The participants of this study, inhabitants of both of these agencies, are mostly young native Quechua speakers. They have migrated to the city of Cuzco from mostly surrounding rural Quechua-dominant communities within the Department of Cuzco in order to make a living and obtain a higher quality education than would be available to them in their rural communities of origin.

Here, the examples are taken from recorded and transcribed interviews carried out with twenty-eight CAITH participants and forty-two CdC participants, totaling seventy participants. Sixty-eight of these seventy participants claim Quechua as their first language and two of these participants claim to have acquired Quechua and Spanish 
simultaneously. In 2003, at the time of the interviews, these participants ranged in age from eleven to fifty-eight years old. All of the participants claimed to have begun their acquisition of Spanish by the age of eighteen, and fifty-four of the seventy participants claimed to have begun their acquisition of Spanish by the age of thirteen. Most of the participants began elementary school within their communities of origin before migrating to the city of Cuzco. Some received their schooling in Quechua, others had bilingual Quechua-Spanish elementary schooling, while still others received their elementary schooling through the means of Spanish. Therefore, some of these participants began their acquisition of Spanish while still living within their rural communities of origin while others began their L2 acquisition upon their arrival to Cuzco. No participant had spent more than eighteen years in school and fifty of the seventy participants had attended school for less than ten years. At the time of the data collection, the vast majority of the study participants claimed to use more Spanish on a daily basis than Quechua.

All of the seventy interviews were carried out in Spanish, lasting approximately thirty minutes each. During the interviews, each participant was asked twenty-two open-ended questions on the topic of language attitude. Each of the twenty-two questions consisted of one or two parts. Sixteen of these twenty-two questions were asked using verbs in the present tense, such as ¿Cómo es la cultura quechua?, 'What is the Quechua culture like?'. Three of the questions were asked using the future tense, such as $\dot{ }$ Vas a usar el quechua en el futuro en tu trabajo? ¿Cómo?, 'Are you going to use Quechua in your future job? How?'. One question was asked using the conditional, ¿Votarías por un candidato quechuahablante? ¿Por qué?, 'Would you vote for a Quechua-speaking candidate? Why?'. One question was asked using both the past subjunctive and the conditional, Si no hablaras quechua, ¿sientes que podrías identificarte con la cultura quechua?, 'If you didn't speak Quechua, do you feel that you would be able to identify yourself with the Quechua culture?'. Finally, one question was asked using the present perfect verb tense, ¿Alguna vez te has negado a hablar quechua? ¿Por qué?, 'Have you ever denied speaking Quechua? Why?'.

The Andean Spanish examples presented throughout this paper contain a variety of cross-linguistic features from the Quechua language beyond those resulting from the influence of the epistemic system. These features are not examined here, as this would be outside the scope of this work. The English translations of the examples presented here, rather than faithfully representing any unsystematicities or nonstandard elements caused by the intense cross-linguistic influence present in the participants' speech, intend to offer accounts of the messages conveyed by the examples in a fluent, Standard English form. As no significant differences were observed in the Andean Spanish speech of male study participants versus that of female study participants, while discussing examples obtained from both males and females, the participants will be referred to as 'he' throughout this paper.

The following are techniques employed by the author in order to reduce the distance between herself and the interviewees: (1) by the time the Language Attitude Interviews were carried out, the author had already met and completed multiple other interviews with the participants, thus resulting in familiarity and reduced anxiety between the interviewer and interviewee, (2) although participants were being recorded, the interviews were carried out in an informal manner (including an informal tone and an 
informal setting), further reducing anxiety, (3) the interview questions were open-ended, thus allowing participants to speak freely, (4) participants were given the opportunity to say as much or as little in response to each of the questions as they desired, and (5) participants spoke about their feelings and attitudes toward their two languages, a very real and important topic for them.

\section{ANALYSIS.}

4.1. REINTERPRETATION OF THE SPANISH PRESENT AND PAST PERFECT VERB TENSES. The hypothesis mentioned above that the Spanish perfect tenses indicate a contrast in epistemic meaning is not upheld in this data, based on the fact that the participants generally avoided the use of the past perfect in Spanish. Below, in Table 1 , are the total counts and relative percentages of how many of the seventy participants used each of four different past tenses in Spanish during the course of their interviews.

\begin{tabular}{|r|c|c|c|c|} 
& Present Perfect & \multicolumn{1}{|c|}{ Imperfect } & Preterite & Past Perfect \\
Count & 48 & 43 & 25 & 4 \\
\cline { 2 - 5 } Percent & $68.57 \%$ & $61.43 \%$ & $35.71 \%$ & $5.71 \%$ \\
\hline
\end{tabular}

Table 1. Past Verb Tenses

As shown in the excerpts below, each of the four participants, out of the subset of seventy participants, who produced instances of the past perfect (two participants produced the past perfect verb tense twice and two participants produced the past perfect once) clearly communicated information that was gathered through her direct, first-hand experience. Each of these four participants is a female inhabitant of CAITH, who claimed Quechua as her first language. While one of these four participants had spent over half her life in Lima and had completed eighteen years of schooling in Spanish, including at the university level, the background and life experiences of the other three participants who were found to employ the past perfect were not significantly different than those of the other sixty-six participants.

In answer to the question of why some Quechua speakers deny that they speak their language, one member of CAITH responded with an anecdote, including the following:

(1) Sí, una vez he escuchado hablar con quechua con su mamá. Por gusto me había dicho; se había mentido, decir, 'No hablo cas... quechua'.

'Yes, one time I have heard him speak in Quechua with his mom. For no good reason he had told me; he had lied, saying 'I don't speak Spa... Quechua’’.

In 1, the participant recalls her own conversation with an acquaintance that lied to her, saying that he was not able to speak Quechua, although she later observed him speaking in Quechua with his mother.

In response to the question of why she does not identify herself with the Quechua culture, another member of CAITH answered as follows, recalling her own childhood and life experiences: 
(2) Bueno, yo de niña me había acostumbrado... porque yo nunca la había vivido desde los siete años.

'Well, I had gotten used to it as a child... because I hadn't lived it (the Quechua lifestyle) since I was seven years old.'

In reply to the question of what her future job will be, another member of CAITH responded in the following way, expressing her own experience:

(3) En... yo no había pensado. No. Sí, yo quiero ser profesora. 'In...I hadn't thought about it. No. Yes, I want to be a teacher.'

And finally, in response to the question of whether she reads the newspaper or anything else in Quechua and how often, another member of CAITH replied, again mentioning something of her own experience:

(4) Sí, acá, unos libros... Hay unos de los campos. Ay, no sé qué libro había sido, sí.

'Yes, here, some books... There are some from the countryside. Ay, I don't know what book it had been.'

While it is true that the instances of past perfect produced by these four speakers centered on personal, direct experience, it is also the case that in the examples provided here, the speakers recall experiences during which they were not completely alert and aware. In 1, the speaker was not aware of the fact that her interlocutor was lying to her at the time. In 2, since the speaker is referring to an experience she had at a young age, she might not have been fully aware of the experience at the time. In example 3, the speaker refers to a topic she had not thought about and of which, therefore, she was not fully conscious. Finally, in 4, the speaker refers to an experience about which she cannot remember the details. If the sole or primary meaning of $-s i /-s$ and $-s q a-$ is not considered to be an indirect information source, but rather something like truth-value, level of certainty, involvement, or responsibility, as these examples of the past perfect evince one of the epistemic meanings claimed for -si/-s and -sqa-, namely, that of being unconscious or not fully aware, it is possible to conclude that these examples of the past perfect do communicate one of the epistemic meanings of the Quechua -si/-s and -sqa-.

However, since only four of the seventy speakers produced the past perfect and did so infrequently, it appears that in general, these participants avoided using the past perfect. Thus, in general, this data does not seem to support the claim that the past perfect in Andean Spanish has been restructured due to the influence of the Quechua epistemic markers, -si/-s and -sqa-. As is evident in Table 1, in general, the participants preferred the present perfect and imperfect tenses while discussing past events.

As this data does not support the findings of others on this issue, as described above, one might question whether the participants of this study might have characteristics that are significantly different from the participants of other investigations on this issue. This is a reasonable possibility in the case of comparing the participants of this study to those of Klee and Ocampo's (1995) study. Klee and Ocampo divided their participants into four groups by social class. Data from participants of the group with the lowest 
socioeconomic status, referred to as "campesinos", was not included among the analyzed data for their study (1995:53). It is likely that at least some of the participants of the present study would be classified as "campesinos" by Klee and Ocampo, based on the social class descriptions presented in their research.

The findings presented here might also suggest that the Quechua language is undergoing a change in its epistemic system, such that Quechua speakers are losing the epistemic markers, -si/-s and -sqa-, along with their corresponding meanings and uses. If these members of the epistemic system are being lost, the influence these markers would exert on Andean Spanish would also disappear. As mentioned above, de Granda has proposed that the use of the -si/-s suffix among Quechua speakers is gradually disappearing (2001:127).

4.2. 'DICE' EPISTEMIC CALQUE. In this data, seventeen of the seventy participants used forms of decir as calques. However, rather than claiming that the use of these calques indicates only that information has been obtained indirectly, the author claims that forms of decir may be used to calque a variety of meanings encompassed by the Quechua epistemic markers, -si/-s and -sqa-, including indirect information source, less certainty, less involvement and less responsibility.

In examples 5 and 6 below, forms of the verb, decir, are used as calques of -si/-s and -sqa- to indicate that information has been obtained through indirect means.

(5) La gente de la ciudad, lo que vive allí, dicen los de discriminan.

'The city people, the ones who live there, dicen descriminate against them.'

(6) Porque es antiguamente, como dicen desde los Incas, nuestros antepasados hablaban quechua.

'It is because in the ancient times, like dicen from (the time of) the Incas, our ancestors used to speak Quechua.'

In example 7 below, a participant employs the use of a form of decir twice while discussing information that he does not agree with:

(7) A veces dicen que, ¿cómo se llama? Quechua es solo hablan los cholos, los indios, campos dicen, pero no es.

'Sometimes dicen that, what is it called? Quechua is only spoken by the cholos, the Indians, (in the) countryside dicen, but it isn't.'

In other words, in 7, this participant expresses disagreement with the idea that Quechua is spoken only by indigenous peasants in the countryside. As this participant does not agree with the concept in question, he does not take responsibility for the truth of the concept, as would be consistent with the use of $-s i /-s$ and $-s q a$ - that some have claimed for Quechua.

In the following example, a participant describes a third party's dishonesty and then expresses his knowledge of the truth: 
(8) Ya no quiere y dice por gusto todo allá, pero la verdad es que sabe hablar quechuas.

'(He) doesn't want (to speak Quechua) anymore and dice everything (is) just for kicks there, but the truth is that (he) knows how to speak Quechua.'

In 8, the use of dice in the first part of the utterance is used to describe another's dishonesty. Therefore, as this participant does not agree with the third party's dishonesty, he does not take responsibility for the truth of the message.

In the following example, a participant puts acquired information about the practices of the Incas into question:

(9) ...¿Qué religión tenían verdaderamente? Según la historia, nos dicen ellos adoraban al sol, al agua, la luna, eso.

'What religion did they really used to have? According to history, dicen they used to worship the sun, the water, the moon, that.'

As this participant puts the information acquired from history into question, he shows he has a lower level of certainty regarding this information.

Further evidence to support the use of forms of decir, 'to say', as calques of -si/-s and -sqa- is that the participants of this study were found to semantically extend the Spanish verb, hablar, 'to speak/talk', in order to encompass the standard meaning and uses of decir. In other words, since an important use of forms of decir is to calque the Quechua epistemics, -si/-s, and -sqa-, in order to simply express the meaning, 'to say', it is hypothesized here that many of these participants resort to a different verb, namely, hablar, in order to avoid being perceived as calquing the Quechua epistemics when this is not intended. In the following three examples, forms of the verb hablar, 'to speak/talk', are used where forms of the verb, decir, 'to say', would be used in standard Spanish.

(10) Los que no entiende quechua no te no entiende lo que estás hablando, ¿no?

'Those who don't understand Quechua don't understand what you're speaking.'

(11) Así como estoy así, hablo palabras. 'Just as I am, I speak words.'

(12) Una persona se ha perdido y habla después, 'No conozco’ así. 'A person has gotten lost and speaks later, 'I'm not familiar (with this place).',

In example 10, rather than hablando, standard Spanish would demand diciendo. In 11, rather than hablo, standard Spanish would include digo. Finally, in 12, rather than habla, this would be put in standard Spanish as dice.

4.3. 'PUES' EPISTEMIC CALQUE. Forty-five of these seventy participants were found to use pues as a function calque for $-m i /-n$ in order to convey direct information 
source, a higher level of certainty, more involvement and more responsibility, as in the following five examples:

(13) Hermoso quechua es pue.

'Quechua is beautiful pue.'

(14) Quechua es bonito es pue.

'Quechua is beautiful pue.'

(15) Porque más nosotros hablamos en castellano acá en ciudad; por eso es pe. 'Because we speak more in Spanish here in the city; that's why pe.'

(16) Porque es quechua es bonito, porque idioma de de Inca es pe sí.

'Because (it) is Quechua is beautiful because it is the language of the Inca pe.’

(17) Porque para el trabajo, hay veces con la gente que no sabe hablar quechua, no puedes conversar así sí pues.

'Because for work, there are times with the people who don't know how to speak Quechua, you can't converse pues.'

While the participants produced pues as a calque in the clause-final position the majority of the time, they also produced the calque in positions other than clause-final on occasion. This may be seen in the following five examples:

(18) Tienen miedo porque porque aquí hablan pue castellano. 'They are afraid because here they speak pue Spanish.'

(19) Porque hay unos no saben pue quechua. 'Because there are some (who) don’t know pue Quechua.'

(20) Puro quechua pues en campo habla pe.

'Only Quechua pues is spoken in the countryside pe.'

(21) Bueno, en campo mayormente se trabaja pues en nuestros productos, crianza de animales...

'Well, in the countryside generally one works pues on our products, the tending of animals ...'

(22) Porque, mira, si no sabría pe castellano, ¿cómo podría educarme?

'Because, look, if I didn’t know pe Spanish, how would I educate myself?'

The author hypothesizes that pues may be used in order to calque the Quechua $-m i /-n$ in all positions within utterances, including the clause-final position. Used as a calque in 
this way, pues refers to the whole utterance in which it appears, serving to indicate how this is to be interpreted.

4.4. SIX OTHER EPISTEMIC CALQUE STRATEGIES FOR QUECHUA $-M I /-N$. Besides the use of pues, based on the data, it is hypothesized that Andean Spanish speakers also frequently use six other strategies for calquing the Quechua epistemic suffix, -mi/-n. These are the use of (1) así, 'like this/that; this way', (2) sí, 'yes', (3) elongated [s] (ssss...) in words that contain the sound [s], (4) nonstandard pluralization, (5) siempre, 'always', and (6) word-final voiceless fricative [r] in words that end with the Spanish sound [r]. Similar to the elongated [s], the word-final voiceless fricative [r] was also frequently elongated or held out. This is consistent with Lipski's (1996:341) finding that syllable-final / $\mathrm{r} /$ becomes a voiceless sibilant in the Peruvian Andes, especially before a pause.

As in the case of pues, it is hypothesized that these six calques are used to convey a direct information source, higher levels of certainty, and greater levels of involvement and responsibility toward the knowledge conveyed. In Table 2 are presented the numbers of participants who were found to use these six calques of the seventy participants as well as the percentages that these counts represent out of the total sample.

\begin{tabular}{|r|c|c|c|c|c|c|} 
& \multicolumn{2}{|c|}{ Así } & Sí & \multicolumn{2}{c|}{ Elongated [s] } & \multicolumn{2}{c|}{ Pluralization } & Siempre & Voiceless [r] \\
\cline { 2 - 7 } Count & 65 & 62 & 59 & 41 & 40 & 40 \\
\cline { 2 - 7 } Percent & $92.86 \%$ & $88.57 \%$ & $84.29 \%$ & $58.57 \%$ & $57.14 \%$ & $57.14 \%$ \\
\hline
\end{tabular}

Table 2. Epistemic Calque Strategies for Quechua -mi/-n

As is the case with the Quechua epistemic suffix, $-m i /-n$, and as has been found for the use of pues, these six calques followed words of every grammatical category. In the data, each of these six calque elements appeared in utterances alone, repeated, and along with others of the six calques and pues. Like pues, these six calques occurred most often in the clause-final position. Some of these six calques have already appeared in the examples presented throughout this paper. For the sake of clarity and organization and to avoid confusion, discussion of these calques has been reserved for this section. For this reason, these calques have not been represented in the English translations of previous examples. In the examples below, the elongated [s] will be represented as a bold '[s]', nonstandard pluralization will be represented by a bold ' $\mathrm{s}$ ', and the voiceless [r] will be represented as a bold ' $[\mathrm{r}]$ '.

Repeated here are examples 16 and 17 of the previous section, now numbered as 23 and 24:

(23) Porque es[s] quechua es bonito, porque idioma de de Inca es pe sí.

'Because (it) is[s] Quechua is beautiful because it is the language of the Inca pe sí.'

(24) Porque para el trabajo, hay veces con la gente que no sabe hablar quechua, no puedes[s] conversar así sí pues. 
'Because for work, there are times with the people who don't know how to speak Quechua, you can’t[s] converse así sí pues.'

In 23 and 24, two of the six calque strategies, así and sí, occur beside pues or pe and the elongated [s] occurs earlier in both utterances.

The following five examples show pues and its variants occurring in the same utterances as the elongated [s], así, sí, and nonstandard pluralization:

(25) Algunos[s] algunos pue cuando vienen su paisanos así se olvidan su caste su quechua pues.

'Some[s] some pue when their fellow countrymen come así they forget their Spa their Quechua pues.'

(26) Porque es con castellano se practica las educaciones pue sí. 'Because it is with Spanish that one practices educations pue sí.'

(27) Otros hablan pe quechua otros castellanos. 'Some speak pe Quechua others Spanishs.'

(28) De esos tienen vergüenza pue sí. 'They are ashamed of them pue sí.'

(29) Otra idioma saben pe así.

'They know another language pe así.'

Like the calque, pues, the constellation of these six other discourse marker calques for -mi/-n do not carry referential meaning but are attached to utterances in order to designate how these should be understood by the hearer, based on the attitude toward the information expressed by the speaker through the use of these calques. In order to assume their calque function in Andean Spanish, three of the six calques that have referential meaning in standard Spanish, the adverbs, así, sí and siempre, have undergone a process of degrammaticalization as they have lost their functional value at the propositional level. Therefore, rather than adding any referential meanings of 'like this/that; this way', 'yes' or 'always' to utterances in which the así, sí and siempre calques are used, like pues, these calques communicate such notions as assertion, confirmation, a direct information source, a higher level of certainty, and more involvement and responsibility on the part of the speaker toward the message.

In the following three examples, the referential meaning of 'always' for siempre in standard Spanish would be in conflict with other propositional content contained within the three utterances, thereby providing more evidence that the use of siempre by these three speakers carries another purpose, namely of calquing the Quechua $-m i /-n$. In response to the question of whether and how often he listens to Quechua on the radio, one participant responded as follows:

(30) Yo de vez en cuando siempre escucho en ¿cómo se llama?, radios en quechua. 
'I once in a while siempre listen to, what's (it) called? radios in Quechua.'

When asked why it is important to speak Spanish, another participant responded:

(31) Porque siempre la gente mayormente habla castellano.

'Because siempre the people speak Spanish the majority of the time.'

When asked when he feels proud of speaking Quechua, another answered:

(32) Y entonces, bueno, a veces pe en bromas de cualquier cosa entonces yo siempre converso quechua.

'And so, well, sometimes pe in jokes about anything I siempre converse in Quechua.'

The fact that the participants produced the six calques at a high frequency and the fact that they are often combined together and also along with pues provides more evidence that, rather than communicating referential meaning, these are used in order to express epistemic meaning. This may be observed in the following examples. When asked why he prefers Quechua, one participant replied:

(33) Porque siempre me gusta hablar en, cuando voy a mi pueblo así, con mis tíos, así. Sí, es bonito, sí. No, no puedo olvidarle, sí.

'Because siempre I like to speak in, when I go to my town así with my aunts and uncles así. Sí it is beautiful sí. No, I can’t forget it sí.'

When asked what the Quechua culture is like, another answered:

(34) Es[s] de los de los Incas que dejaron su esto porque ellos hablaban en quechua sí.

'It is[s] from the Incas who left their stuff because they used to speak in Quechua sí.’

Upon being asked why he would vote for a Quechua-speaking candidate, a participant said:

(35) Nos daría más educación así mediante quechua. Nos daría más educación así, ¿no? como sabe quechua así.

'He would give us more education así through the means of Quechua. He would give us more education así, right? since he knows Quechua así.'

In the following examples, participants incorporate use of the voiceless fricative [r] calque in combination with the other calques for $-m i /-n$. When questioned as to why he thinks Quechua is more beautiful than Spanish, one participant answered:

(36) Porque bonito es o para conversar así para enseñar[r], sí.

'It is beautiful because or in order to converse así in order to teach[r] sí.' 
When asked why it is important to speak Spanish, another participant responded:

(37) Es para para ingresar[r] a los trabajos así.

'It is in order to gain[r] employment así.'

When questioned as to why some Quechua speakers deny that they speak their language, a participant replied:

(38) Porque porque algunos niegan su su hablar quechua porque tienen miedo así hablar[r].

'Because some deny (that they) speak Quechua because they are afraid así to talk[r].'

Finally, when asked why it is important to speak both Quechua and Spanish, another answered:

(39) Porque es[s] siempre los dos es bueno sí para hablar[r] sí.

'Because it is[s] siempre both are good sí in order to speak[r] sí.'

It is interesting to note that each of the six calque strategies as well as pues contains a voiceless fricative. Excluding the voiceless fricative [ $\mathrm{r}$ ], the other six calques (including pues) for the Quechua -mi/-n include the voiceless fricative [s]. Since the Quechua epistemic marker in opposition with $-m i /-n,-s i /-s$, contains the voiceless fricative [s], one might wonder whether the discourse markers claimed here as calques of $-\mathrm{mi} / \mathrm{n}$ may actually be calquing the Quechua -si/-s or be derived from the Quechua -si/-s. In opposition to this notion, the author here provides the following possible rationale as to why these six calques and pues might carry the common quality of the voiceless fricative.

The use of siempre, así, pues, the elongated [s], nonstandard pluralization and the voiceless fricative $[\mathrm{r}]$ as calques of $-\mathrm{mi} /-n$ may be motivated by the phonetic form of the sí calque. The siempre and así calques both contain the sound sequence [si]. The elongated [s] and nonstandard pluralization calques contain the first sound of the sí calque, namely [s]. Finally, the voiceless fricative [r] contains the voiceless fricative quality of the first sound of the sí calque, [s].

The meaning of the standard Spanish adverb, sí, 'yes', has much in common with the semantics and pragmatics of the Quechua epistemic marker, -mi/-n. Above, -mi/-n has been described as communicating affirmation, confirmation, a higher level of certainty, more involvement and responsibility of the speaker toward the message at hand and that information has been obtained through direct experience. Like -mi/-n in Quechua, the adverb, sí, 'yes', may be used in standard Spanish in order to communicate affirmation, confirmation, assertion, authentication, verification, and validation. The Quechua epistemic suffix, -mi/-n, has also commonly been referred to as a 'validator', reflecting its role as a marker used to validate or confirm assertions. This commonality of meaning between the standard Spanish adverb, sí, 'yes', and the Quechua epistemic marker, -mi/$n$, may serve to grant the sí calque a special status that is carried over through phonetic form to the other calques for $-m i /-n$. 
Schiffrin (1987) and Schwenter (1995) have both discussed the issue of the link between discourse markers and the meanings of their lexical origins. Schiffrin (1987:54) asks, "Is there some property of the elements used as markers that contributes to their functions?”. Also, Schwenter (1995:870) has explained that the use of discourse markers cannot be understood without considering their connection to the content meaning of their source words in the lexicon. He suggests that something of the meaning of the source word remains with the discourse marker, limiting its usage. Both Schiffrin and Schwenter's thoughts on this matter provide some support for the hypothesis that the lexical content meaning of the standard Spanish adverb, sí, 'yes', is linked to the use of sí as a discourse marker that calques the Quechua $-m i /-n$.

5. CONCLUSION. In conclusion, throughout this paper, the author has sought to clarify and inform the current debates in the literature regarding the semantics and pragmatics of the Quechua epistemic system as well as the ways in which the Quechua epistemic markers exert cross-linguistic influence on Andean Spanish. Based on the analysis of seventy recorded and transcribed interviews on the topic of Quechua and Spanish language attitude among twenty-eight female study participant members of CAITH and forty-two male study participant members of the CdC, evidence has been found that both corroborates and contradicts previous claims regarding the debates at hand.

Following Weber (1986) and Nuckolls (1993), the data support a model of the Quechua epistemic system in which each of the epistemic markers may express meaning beyond information source, to include such notions as levels of certainty, involvement, and responsibility.

The finding that these seventy participants seemed to avoid the use of the past perfect in Spanish and clearly communicated information that was gathered through direct, firsthand experience in the few instances when the past perfect was employed contradicts the claim made by Klee and Ocampo (1995), Lipski (1996), Escobar (1997), Lee (1997) and de Granda (2001), among others, that the Spanish present perfect and past perfect verb tenses indicate a contrast in epistemic meaning. Two possible reasons were discussed that might account for this contradiction, namely, (1) possible differences among the participants of this study and those of other studies on this topic, and (2) Quechua language change and the loss of the -si/-s and -sqa- epistemic markers.

Similar to the findings of Klee and Ocampo (1995), Lipski (1996) and de Granda (2001), forms of the Spanish verb, decir, 'to say', were found to be used to calque the variety of meanings encompassed by the Quechua epistemic markers, -si/-s and -sqa-, including an indirect information source, less certainty, less involvement and less responsibility. The fact that many of the seventy participants semantically extended the Spanish verb, hablar, 'to talk', in order to encompass the standard meaning and uses of decir provided further evidence to support the claim that forms of decir are used to calque - si/-s and - sqa-.

The findings presented in this paper support those of Zavala (2001), who found the Spanish pues, 'well; then; since; therefore; because', to have lost its grammatical meaning and functionality at the sentence level and to have taken on a discourse marker role as a calque of the Quechua epistemic suffix, -mi/-n, indicating such notions as that information has been obtained directly, a higher level of certainty and more involvement 
and responsibility regarding the message at hand. However, while Zavala found her participants to always produce pues as a calque in the clause-final position, these participants occasionally produced this calque in other positions, resulting in no change of pragmatic meaning. Besides the use of pues, these participants were also found to frequently use six other strategies for calquing the Quechua epistemic suffix, $-m i /-n$. These are the use of (1) así, 'like this/that; this way', (2) sí, 'yes', (3) elongated [s] (ssss...), (4) nonstandard pluralization, (5) siempre, 'always', and (6) word-final voiceless fricative $[r]$. As for pues, these six calques have undergone a process of degrammaticalization and no longer carry referential meaning but are attached to Andean Spanish utterances in order to designate how these should be understood by the hearer, based on the attitude toward the information expressed by the speaker through the use of these calques. The high frequency of use of the six calques and the fact that they are often combined together and also along with pues provides more evidence that, rather than communicating referential meaning, these are used in order to express epistemic meaning.

Finally, a rationale was provided as to why the six calques and pues might carry the common quality of the voiceless fricative. It was proposed that the use of siempre, así, pues, the elongated [s], nonstandard pluralization and the voiceless fricative [r] as calques of $-m i /-n$ may be motivated by the phonetic form of the calque, sí and that the commonality of meaning between the standard Spanish adverb, sí, 'yes', and the Quechua epistemic marker, -mi/- $n$, in communicating affirmation, confirmation, assertion, authentication, verification, and validation may serve to grant the sí calque a special status that is carried over through phonetic form to the other calques for $-m i /-n$. Schiffrin (1987) and Schwenter's (1995) thoughts on the matter provide some support for this hypothesis that the lexical content meaning of the standard Spanish adverb, sí, 'yes', is linked to the use of sí as a discourse marker that calques the Quechua -mi/-n.

\section{REFERENCES}

Aráoz, Dora and Salas, Américo. 1993. Gramática Quechua. Sicuani, Peru: Instituto de Pastoral Andina.

Cusihuaman, Antonio. 1976. Gramática Quechua, Cuzco Collao. Lima, Peru: Instituto de Estudios Peruanos.

Dedenbach-Salazar-Saenz, Sabine. 1997. Point of View and Evidentiality in the Huarochiri Texts: Peru, 17th Century. Creating Context in Andean Cultures, ed. by Rosaleen Howard-Malverde, 149-67. New York: Oxford University Press.

De Granda, Germán. 2001. Estudios de lingüística andina. Lima, Perú: Pontificia Universidad Católica del Perú.

Escobar, Anna María. 1997. Contrastive and Innovative Uses of the Present Perfect and the Preterite in Spanish in Contact with Quechua. Hispania 80. 859-870.

Hardman, M.J. ed. 1981. The Aymara Language in Its Social and Cultural Context. Gainesville: U Presses of Florida.

Klee, Carol A. and Ocampo, Alicia. 1995. The Expression of Past Reference in Spanish Narratives of Spanish-Quechua Bilingual Speakers. Spanish in Four Continents, Studies in Language Contact and Bilingualism, ed. by Carmen Silva-Corvalán. 52-70. Washington D.C.: Georgetown University Press.

Laprade, Richard A. 1981. Some Cases of Aymara Influence on La Paz Spanish. The Aymara Language in Its Social and Cultural Context, ed. by M. J. Hardman. 207-227. Gainesville: U Presses of Florida.

Lee, Tae Yoon. 1997. Morfosintaxis amerindias en el español americano, Desde la perspectiva del quechua. Madrid: Ediciones Clásicas, Universidad Complutense de Madrid.

Lipski, John M. 1996. El Español de América, Madrid: Ediciones Cátedra. 
Martin, E. Herminia. 1981. Data Source in La Paz Spanish Verb Tenses. The Aymara Language in Its Social and Cultural Context, ed. by M. J. Hardman. 205-206. Gainesville: U Presses of Florida.

Nuckolls, Janis B. 1993. The semantics of certainty in Quechua and its implications for a cultural epistemology. Language in Society 22. 235-255.

Schiffrin, Deborah. 1987. Discourse Markers. Cambridge: Cambridge University Press.

Schwenter, Scott A. 1995. Some reflections on o sea: A discourse marker in Spanish. Journal of Pragmatics 25. 855-874.

Stratford, Dale. 1991. Tense in Altiplano Spanish. Sociolinguistics of the Spanish-Speaking World, ed. by Carol A. Klee and Luis Ramos-García. 163-181. Tempe: Bilingual Press.

Weber, David J. 1986. Information Perspective, Profile, and Patterns in Quechua. The Linguistic Coding of Epistemology, ed. by Wallace Chafe and Johanna Nichols. 137-155. Norwood, NJ: Ablex.

Wölck, Wolfgang. 1987. Pequeño breviario quechua. Lima: Instituto de Estudios Peruanos.

Zavala, Virginia. 2001. Borrowing evidential functions from Quechua: The role of pues as a discourse marker in Andean Spanish. Journal of Pragmatics 33. 999-1023. 